\title{
An Effective Safety Handling System for Construction Industry in Kerala
}

\author{
Elsa Maria Jose, P. Jagannathan, S. Venkatesh
}

\begin{abstract}
The construction industry plays a prominent part in the progress of a country socially and economically. Nowadays construction industry has grown profit driven and the management focuses more on completing the projects on time neglecting safety of the workers. Construction works involving intricate works leading to accidents or injuries resulting in loss of life and body parts are rampant. So a proper safety management system is required to avoid accidents and improve safety at construction sites. Factors affecting safety at construction workplaces were identified and was surveyed through a quantitative questionnaire and analysed to form a basis for the total construction safety management model. The Total Construction Safety Management (TCSM) based on the PDCA modelling is proposed to improve safety at construction sites. This model can act as a guide to the present organizations and helps them to implement safety in quicker manner at construction site.
\end{abstract}

Keywords : Safety management system, Plan Do Check Act, Construction worksites, accidents

\section{INTRODUCTION}

Safety is the state of being safe, it is the condition of being protected from harm or other non-desirable outcomes [1].Construction industry is a combination of contrasting organisations, and the same intricacy can be seen in construction worksites. Construction workers do diverse tasks and their next job could be an entirely disparate construction project [3].The construction sector has a perilous nature across the globe. Anyhow, in certain countries there is the deficiency of standard recording and notifications system for accidents at construction worksites while in countries such as India, the systems exist but their implementation is an issue. In both cases, accident statistics are either deficient or unreported and this generates a situation where safety is unobserved [2].

The literature study concludes that falls are the most serious hazard [4]. The construction industry has no real safety culture. Hazards at construction workplaces include

Revised Manuscript Received on February 05, 2020.

* Correspondence Author

P. Jagannathan*, Department of Civil Engineering, SRM Institute of Science and Technology, Kattankulathur, India.

Email: jaganjayanthi6068@gmail.com

Elsa Maria Jose, Department of Civil Engineering, SRM Institute of Science and Technology, Kattankulathur, India. Email: elsamariajose96@gmail.com

S. Venkatesh, Department of Civil Engineering, SRM Institute of Science and Technology, Kattankulathur, India. Email: Venkateshsince1996@gmail.com

(C) The Authors. Published by Blue Eyes Intelligence Engineering and Sciences Publication (BEIESP). This is an open access article under the CC BY-NC-ND license (http://creativecommons.org/licenses/by-nc-nd/4.0/) falls, electrical accidents, injury due to projected reinforced roofs, contact with potentially harmfull substances, accident due to lifting equipments, loose scaffolding, machinery, tunnelling, poison, gassing, toxic materials, impact noise and excavators, mental stress etc. Many owners and contractors do not support safety. Between developed and developing countries, main differences are found in developed countries, such as extant of legislation and its efficacious implementation and well aware of hazards in working environment by vigorous training programme.

In developing countries like India, legislation is there, still enforcement agencies have to be identified and a few state governments have to frame the building and other construction workers rules. Workers turnover is more and migrant in nature. Awareness about hazards is less, compared to developed countries. In developing countries other major impact on this sector is the lack of research and development on construction safety. So this had motivated the researcher to address these issues and to reduce the accidents rate. A framework on safety system at construction sites is needed to address the above issues. Therefore the present research will address the challenges and risks faced by construction industries. Following are the objectives of the study:

- To identify the factors affecting safety in construction industry.

- To analyse the major factors affecting safety with respect to construction industry.

- To develop a new model for construction safety management system

\section{PROBLEM IDENTIFICATION}

The recurrent nature of most accidents at construction sites shows that the construction industry is unique [2].Safety in construction industry is undoubtedly a major issue. The construction industry is an important sector of any national economy. But the high rate of accidents and injuries at construction worksites makes it a risky sector. The safety record of the construction industry is dissatisfying and this high rate of injury are primarily due to meagre and unsatisfactory safety management system. So it is necessary to develop a safety management system and implement the safety management systems in site to avoid accidents. The present research work surveys the drawbacks in the existence safety performance measurement tools and developed a framework for new safety performance tool. In general, the safety management is considered as the most important concept in the construction site to reduce the number of accidents, injuries and fatalities.

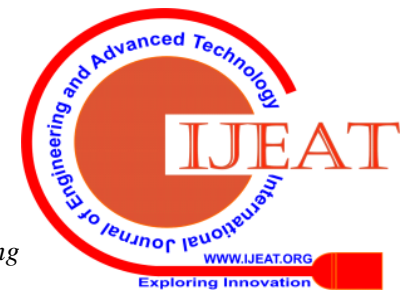


It is necessary for Indian construction industry to find the factors affect safety at construction site, because of lack of research in these areas. The present research work has taken some important factors to know the level of safety maintained at construction site in India. As a result, safety management tends to gain importance in construction industry in the recent years. This research analyses how safety management strategies could be administered in an appropriate manner in order to avoid accidents in construction sites. This study is conducted with reference to construction industries in the state of Kerala.

\section{FACTORS AFFECTING SAFETY}

The factors affecting safety were identified through literature survey. The main factors affecting safety are 1) Management perception and attitude 2) Self-assessment 3) Personal care and location 4) Perceptions about equipment used 5) Safety communication and feedback 6) Safety rules and procedures 7) Safety promotion policies 8) environmental conditions 9) Substance abuse at site 10) technical factors

\section{METHODOLOGY}

The first step in the project is the collection of literatures. All the literatures that match the objectives of the project are collected. The literatures were collected and reviewed for the factors which influence safety at construction sites. Based on the factors that are identified from the literature, the quantitative questionnaire is framed which is distributed to 11 respondents from worker side of 20 construction companies making a total of 220 respondents. The collected data is then analysed in SPSS 24 using Chi Square Test, ANOVA, Correlation and Simple Percentage Method. Finally based on the analyses, a new model of construction safety management at site is developed using the PDCA cycle.

\section{RESULTS AND DISCUSSION}

The quantitative questionnaire framed using the factors affecting the safety was statistically analysed using the software SPSS 24. Statistical analysis includes 1) Simple percentage method 2) Chi square test 3) Karl Pearson correlation coefficient 4) Analysis of Variance (ANOVA).

\section{A. Simple Percentage Analysis}

Simple percentage analysis is used to compare more than two sets of data sample. The frequency and percentage of the demographic profile of respondents is given in the table I. Demographic profiles include age, gender, marital status and designation.

From the table II it is clear that factor which has the top rated factor is equipment perception with a mean value of 3.901 and standard deviation of 0.385 . The second top factor is personal care and location, followed by substance abuse at site, technical issues, safety rules and procedures, safety communication and feedback, self-assessment, environmental conditions, management perception and attitude towards safety. The factor which is least rated is safety promotion policies with a mean value of 2.536 and a standard deviation of 0.266 .
Table-I: Demographic profile of respondents

\begin{tabular}{|c|c|c|c|}
\hline $\begin{array}{l}\text { Background } \\
\text { information }\end{array}$ & Category & Frequency & Percent \\
\hline \multirow[t]{2}{*}{ Gender } & Male & 185 & 93 \\
\hline & Female & 14 & 7 \\
\hline \multirow{4}{*}{$\begin{array}{l}\text { Age group (in } \\
\text { years) }\end{array}$} & $20-30$ & 58 & 29 \\
\hline & $21-40$ & 89 & 44 \\
\hline & $41-50$ & 36 & 18 \\
\hline & $51-60$ & 17 & 8.5 \\
\hline \multirow[t]{2}{*}{ Marital status } & Married & 173 & 86.5 \\
\hline & Unmarried & 27 & 13.5 \\
\hline \multirow[t]{12}{*}{ Designation } & Mason & 57 & 28.5 \\
\hline & Carpenter & 7 & 3.5 \\
\hline & Painter & 20 & 10.0 \\
\hline & Scaffolder & 20 & 10.0 \\
\hline & Foreman & 3 & 1.5 \\
\hline & Bar bender & 8 & 4.0 \\
\hline & Electrical worker & 1 & 0.5 \\
\hline & KCV operator & 1 & 0.5 \\
\hline & Crane operator & 10 & 5.0 \\
\hline & Cable operator & 2 & 1.0 \\
\hline & Electrician & 13 & 6.5 \\
\hline & Helper & 58 & 29 \\
\hline
\end{tabular}

Table -II: Descriptive statistics

\begin{tabular}{|l|l|l|l|l|}
\hline Factor & Minimum & Maximum & Mean & $\begin{array}{l}\text { Standard } \\
\text { deviation }\end{array}$ \\
\hline $\begin{array}{l}\text { Management } \\
\text { perception and } \\
\text { attitude }\end{array}$ & 2.12 & 3.965 & 2.95 & 0.547 \\
\hline $\begin{array}{l}\text { Self -assessment } \\
\text { Personal care } \\
\text { and location }\end{array}$ & 2.395 & 4.05 & 3.394 & 0.533 \\
\hline $\begin{array}{l}\text { Perception about } \\
\text { equipment }\end{array}$ & 3.52 & 3.94 & 3.752 & 0.214 \\
\hline $\begin{array}{l}\text { Safety } \\
\text { communication } \\
\text { and feedback }\end{array}$ & 3.295 & 3.765 & 3.52 & 0.244 \\
\hline $\begin{array}{l}\text { Safety rules and } \\
\text { procedures }\end{array}$ & 3.285 & 4.205 & 3.615 & 0.430 \\
\hline $\begin{array}{l}\text { Safety promotion } \\
\text { policies }\end{array}$ & 2.255 & 2.57 & 2.536 & 0.266 \\
\hline $\begin{array}{l}\text { Environmental } \\
\text { conditions }\end{array}$ & 2.835 & 3.555 & 3.195 & 0.509 \\
\hline $\begin{array}{l}\text { Substance abuse } \\
\text { at site }\end{array}$ & 2.535 & 4.31 & 3.751 & 0.618 \\
\hline \begin{tabular}{l} 
Technical issues \\
\hline
\end{tabular} & 2.61 & 4.52 & 3.642 & 0.710 \\
\hline
\end{tabular}

\section{B. Chi Square test}

(a) Null-Hypothesis (Ho): Designation of the respondent is independent towards their opinion towards raising safety issue

Alternate Hypothesis: Designation of the respondent is not independent towards their opinion towards raising safety issue 
Table-III: Chi square test result for proposed hypothesis(a)

\begin{tabular}{|l|l|l|l|}
\hline & Value & df & $\begin{array}{l}\text { Assymptotic } \\
\text { significance }\end{array}$ \\
\hline $\begin{array}{l}\text { Pearson chi } \\
\text { square }\end{array}$ & $31.944^{\mathrm{a}}$ & 4 & .912 \\
\hline $\begin{array}{l}\text { Likelihood } \\
\text { ratio }\end{array}$ & 25.675 & 4 & .988 \\
\hline $\begin{array}{l}\text { No of valid } \\
\text { cases }\end{array}$ & 200 & & \\
\hline
\end{tabular}

Pearson chi square value $=.912$

Level of significance $=.05$

$\mathrm{P}>\mathrm{L}$

$.912>.05$

Hence, null hypothesis is accepted.

From the table we can infer that designation of the respondent is not independent towards their opinion towards raising safety issue.

(b) Null hypothesis(Ho): Gender of the respondents is independent towards their opinion on opportunities of staff member to contribute to safety issues.

Alternate Hypothesis: Gender of the respondents is independent towards their opinion on opportunities of staff member to contribute to safety issues.

Table-IV: Chi square test results for the proposed hypothesis(b)

\begin{tabular}{|l|l|l|l|}
\hline & Value & df & $\begin{array}{l}\text { Assymptotic } \\
\text { significance }\end{array}$ \\
\hline $\begin{array}{l}\text { Pearson chi } \\
\text { square }\end{array}$ & $1.916^{\mathrm{a}}$ & 4 & .751 \\
\hline $\begin{array}{l}\text { Likelihood } \\
\text { ratio }\end{array}$ & 1.899 & 4 & .754 \\
\hline $\begin{array}{l}\text { No of valid } \\
\text { cases }\end{array}$ & 200 & & \\
\hline
\end{tabular}

Pearson chi square value $=.751$

Level of significance $=.05$

$\mathrm{P}>\mathrm{L}$

$.751>.05$

Hence, null hypothesis is accepted

From the results we can infer that gender of the respondents is independent towards their opinion on opportunities of staff member to contribute to safety issues since the hypothesis is rejected.

\section{Karl Pearson Correlation Coefficient}

Null hypothesis (Ho): There exists a correlation between management perception and attitude towards safety and occurrence of accidents at site

Alternate Hypothesis: There is no correlation between management perception and attitude towards safety and occurrence of accidents at site

Table -V: Correlations between management perception and attitude towards safety and occurance of accidents at construction sites

\begin{tabular}{|l|r|r|}
\hline $\begin{array}{l}\text { Pearson } \\
\text { correlation }\end{array}$ & 1 & -0.423 \\
\hline Sig & & 0 \\
\hline $\mathbf{N}$ & 200 & 200 \\
\hline $\begin{array}{l}\text { Pearson } \\
\text { correlation }\end{array}$ & -0.423 & 1 \\
\hline Sig & 0 & \\
\hline $\mathbf{N}$ & 200 & 200 \\
\hline
\end{tabular}

$\mathrm{P}$ value $=.423$

Level of Significance $=.05$

$\mathrm{P}>.05$

Hence Hypothesis is accepted
The results of correlation shows that the hypothesis that there exist a correlation between management perception and attitude towards safety and occurrence of accidents at site is accepted.

D. Analysis of variance (ANOVA)

(a) Null Hypothesis(Ho): There is no significant difference between age of the respondents and their opinion on individuals with substance use disorder increases the risk of accidents at construction site.

Alternate Hypothesis: There is significant difference between age of the respondents and their opinion on individuals with substance use disorder increases the risk of accidents at construction site.

Table-VI: One way ANOVA between age and substance abuse factor at construction worksites

\begin{tabular}{|l|l|l|l|l|l|}
\hline & $\begin{array}{l}\text { Sum of } \\
\text { squares }\end{array}$ & df & $\begin{array}{l}\text { Mean } \\
\text { square }\end{array}$ & $\mathbf{f}$ & sig \\
\hline $\begin{array}{l}\text { Between } \\
\text { groups }\end{array}$ & 0.420 & 3 & 0.140 & 0.944 & 0.420 \\
\hline $\begin{array}{l}\text { Within } \\
\text { groups }\end{array}$ & 29.080 & 196 & 0.148 & & \\
\hline Total & 29.500 & 199 & & & \\
\hline
\end{tabular}

$\mathrm{P}$ value $=.420$

Level of significance $=.05$

$\mathrm{P}>\mathrm{L}$

$.420>.05$

Hence, Hypothesis is accepted

(b) Null hypothesis (Ho): There is no significant difference between the age of respondents and their opinion on psychological stress which is one among the reason for accidents at construction sites.

Alternate hypothesis: There is significant difference between the age of respondents and their opinion on psychological stress which is one among the reason for accidents at construction sites.

Table -VII: One way ANOVA between age and opinion on psychological stress which leads to accidents at construction sites

\begin{tabular}{|l|l|l|l|l|l|}
\hline & $\begin{array}{l}\text { Sum of } \\
\text { squares }\end{array}$ & df & Mean square & f & sig \\
\hline $\begin{array}{l}\text { Between } \\
\text { groups }\end{array}$ & 01.913 & 3 & 0.638 & 0.882 & 0.451 \\
\hline $\begin{array}{l}\text { Within } \\
\text { groups }\end{array}$ & 141.682 & 196 & 0.723 & & \\
\hline Total & 143.595 & 199 & & & \\
\hline
\end{tabular}

$\mathrm{P}$ value $=.451$

Level of significance $=.05$

$\mathrm{P}>\mathrm{L}$

$.451>.05$

Hence, Hypothesis is accepted.

From the results we can infer that the there is no significant difference between the age of respondents and their opinion on psychological stress which is one among the reason for accidents at construction sites. 


\section{SAFETY MANAGEMENT SYSTEM}

Based on the analysis results, a site safety management system is proposed. Safety management is an organizational concern, which assures that all safety risks have been pinpointed, evaluated and satisfactorily alleviated [5]. Safety management system helps to reduce the accidents at construction workplace. A safety management system must enable the computation of risks to be put through and as a result, the study devises and implements suitable risk reduction measures and provides expedient feedback mechanisms for additional enhancement [8]. There should be a systematic control in the performance of workers, machines and physical environment. An ideal occupational health and Safety Management System (OHSMS) should provide an organized process to minimize potentials of work related injuries and illnesses, increases productivity by reducing direct and indirect costs associated with accident [6].

\section{PDCA MODELLING}

Based on the results of analysis a site based total safety management model is framed plan do check act cycle (PDCA). The PDCA is a checklist and an iterative four step management method for the continuous improvements. The Plan-Do-Check-Act (PDCA) Cycle provides a manageable but effective approach for problem solving and managing change, ensuring that ideas are appropriately tested before committing to full implementation [7]. The PDCA model developed based on the analysis is shown by Fig. 1.

\section{A. Plan}

This stage identifies and defines the works to be done. It includes planning for the health and safety, job hazard analysis and implementation of safety rules and regulations.

\section{B. Do}

This stage includes the proper implementation of the tasks defined in planning phase. This includes safety trainings, safety surveillance, accident reporting systems, monthly awareness classes regarding substance abuse at sites, safety rewards, workers stress reduction activities, safe work permit system and fall protection system.

\section{Check}

This is the evaluation stage. It includes continuous monitoring to check whether it is working properly or not. Safety audits, drug testing programmes and study of accident statistics helps to evaluate the model.

\section{Act}

This is the prevention and correction phase. Feedbacks regarding the safety management is collected from workers and staffs to rectify the mistakes and to make a better plan.

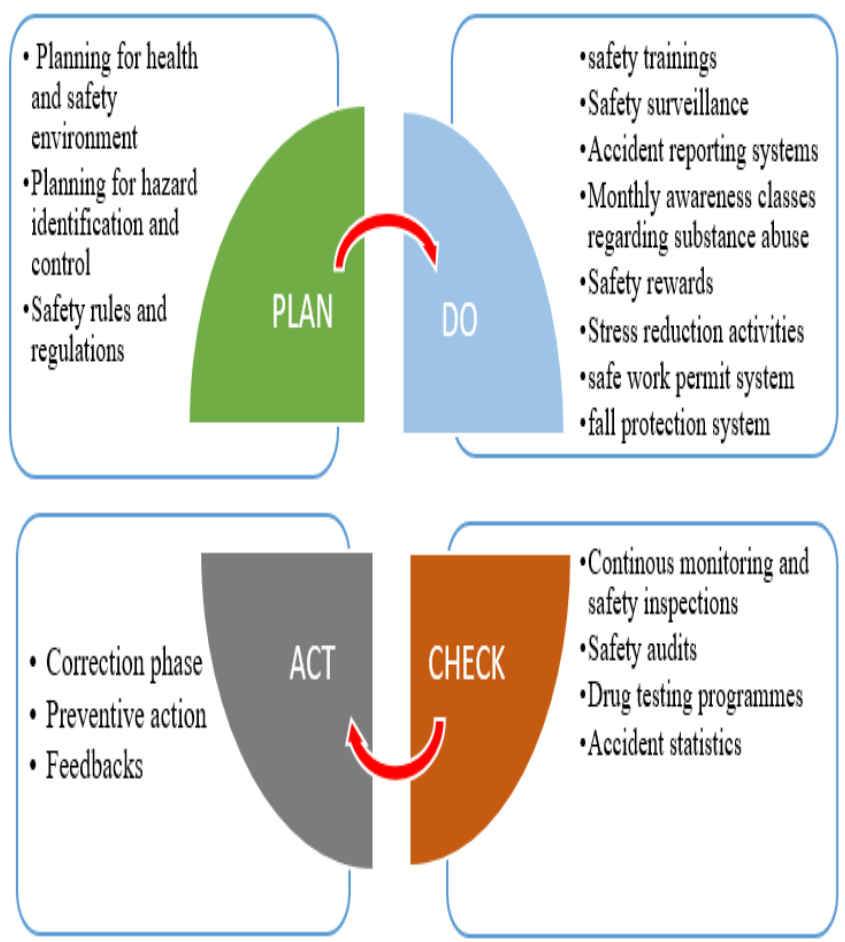

Fig. 1 Total Construction Safety Management Model

\section{CONCLUSION}

The results of the statistical quantitative analysis by chi square test, simple percentage analysis, correlations and ANOVA helped to form a basis for the total safety management model. This site based safety management model developed based on the PDCA cycle helps to minimize the level of accidents at construction sites. Health and safety environment management system provides a structured management approach to control risks. In the safety management system planning, implementation, checking and corrective action phase is included. This site based safety management is a means of stabilizing the systems and social aspects of management and health and safety.

\section{REFERENCES}

1. G. Rajan Kumar, K Anil An effective Safety management system IJRASET,(2017)

2. Patel DA, Jha KN. An estimate of fatal accidents in Indian construction. InProceedings of the 32nd Annual ARCOM Conference (2016) Sep (Vol. 1, pp. 577-586).

3. Jazayeri E, Dadi GB. Construction safety management systems and methods of safety performance measurement: A review. Journal of SafetyEngineering. (2017);6(2):15-28.

4. Chockalingam S, Sornakumar T. An Effective Total Construction Safetymanagement In India.(2012): 409-420

5. Syed Farhat Asad Ali, Prof D.B Desai “ Safety management in construction industry", IJIRSET(2019) Vol 8 , issue 1.

6. Ligade AS, Thalange SB. Occupational health and safety management system (OHSMS) model for construction industry. IJRET: International Journal of Research in Engineering and Technology. (2013):395-9.

7. Patel PM, Deshpande VA. Application of Plan-Do-Check-Act Cycle for Quality and Productivity Improvement-A Review Studies(2015) May;2(6).

8. Kandola B. Risk based approach to fire safety engineering. Fire Engineers Journal( 1997);57:21-6. 


\section{AUTHORS PROFILE}

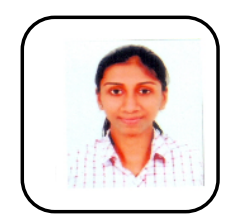

Elsa Maria Jose, Graduated in Civil Engineering from MG University, Kerala. Pursuing Masters in Construction Engineering and Management, SRM Institute of Science and Technology, Kattankulathur, Chennai

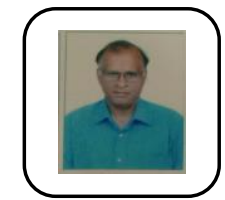

P. Jagannathan, Faculty of Civil Engineering Department, SRM Institute Of Science And Technology, Kattankulathur, Chennai

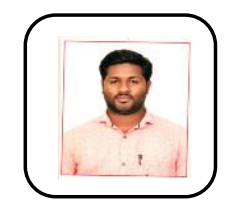

S. Venkatesh, Pursuing $M$ tech in Construction Engineering and Management, SRM Institute of Science and technology, Kattankulathur, Chennai 